\title{
The Economic Lifecycle by Gender - Results Combining Monetary and Time Use Estimates
}

\author{
Fanny A. Kluge
}

\begin{abstract}
In recent decades, we have witnessed profound changes in family size and structure. While marriage rates and the number of children have declined in most industrialised countries, female labour force participation rates have risen significantly. However, while the working hours and wages of women have increased, we continue to observe huge discrepancies in market production by gender in Germany. This results in considerable differences in the economic lifecycle of men and women. The differences diminish if we take unpaid household production, consumption, and caring into account. We find that, after applying this comprehensive approach, the female lifecycle resembles male consumption, income, and transfer patterns. These findings are interesting in the light of future demographic changes, as they suggest that the explicit policy aim of increasing female labour force participation could place constraints on the currently observed division of labour in the market and in the household.
\end{abstract}

Keywords: Economic life cycle - Gender differences · Time use $\cdot$ Household division of labour $\cdot$ Germany

\section{Introduction}

Studies on the differences in patterns of consumption, income, and transfers by age and gender usually focus on monetary estimates. Here, we find a considerable gap between female income and consumption; employment rates and wages are lower for women at all ages. Although recent societal developments have resulted in more gender-egalitarian living arrangements, we still observe a rather traditional division within the labour market for men and women in Germany (male breadwinner model). The monetary approach is certainly important and suitable for many kinds of questions, but it neglects household production and consumption, such as unpaid home services, childcare, and old-age cares. Such services are primarily conducted by women, and if taken into consideration the gap between income and 
consumption for men and women almost vanishes. Male and female differences in time devoted to gainful employment or unpaid home production result in considerable transfers of time and money within households. It is, therefore, very important to include both market and non-market engagement in any study that seeks to provide a comprehensive picture of inter-age and inter-gender resource flows. For example, an increase in female labour force participation could affect the ability of women to provide care for children and the elderly. In addition, a projection showing that smaller birth cohorts who are currently middle-aged will have an increasing number of dependents to support raises questions about whether the provision of care as it is today will be adequate in future. The current patterns and possible future changes affect family formation, education, labour market choices, time allocation, and the accumulation of wealth. The results of this study may contribute to the political discourse in showing the importance of non-market transfers for economic life cycle considerations.

Most economic studies that look at heterogeneous agents by gender focus on the public sector in a welfare state (Owens 2008; Werding 2005), or on differences in labour income from market employment (Andersson et al. 2009; Antonczyk et al. 2010; Oostendorp 2009; Polachek/Xiang 2009). Other studies have acknowledged the link between childbearing and paid work and the importance of the gender perspective (Kreyenfeld 2010; Lechner/Wiehler 2009; Lindh et al. 2005). Dustmann (2005) provided a review of the key differences between men and women that are often mentioned in the literature, such as educational performance, earnings, and sector employment. The generational accounting approach (Auerbach et al. 1999; Raffelhüschen 1999) provides gender-specific results of future taxes net of transfers received during an individual's life. This approach does not, however, show the monetary transfers from a prime earner or taxpayer in the household (typically men) to dependent individuals (children or spouses). In addition, there are non-paid housekeeping and caregiving services that the remaining household members offer in return. These services, numerously studied in itself (Apps/Rees 2000; Becker 1965), should be taken into account in any comprehensive study about gender-specific differences in consumption, income, and transfer patterns. The time allocation differences between men and women have also been studied extensively (Aliaga/ Winqvist 2003; Biddle/Hamermesh 1990). For example, Anxo (2002) and Anxo et al. (2007) looked at the combined monetary and time use estimates for production (labour income as well as home production) in Italy, France, Sweden, and the U.S. Albanesi and Olivetti (2009) also studied gainful employment and housework, and how they relate to the gender wage gap. Burda et al. (2012) analysed both gainful employment and housework by gender, and concluded that the overall amount of work done by men and women is quite comparable. This is referred to as the isowork phenomenon, it also implies that there is gender equality in the total amount of leisure time consumed. They offer several theories for why gender-specific differences in production occurred, including market-based forces, bargaining, and social norms. Another, more comprehensive approach to studying intergenerational transfers of time and money was provided by Albertini et al. (2007). They added 
private channels to the picture, showing comparable intergenerational transfer patterns across Europe; they did not, however, distinguish these patterns by sex.

This paper adds to the discussion by showing how total income, consumption, and transfer patterns of time and money vary for men and women. The novelty of this study is that it jointly estimates monetary and non-monetary income, consumption, and transfer patterns by combining market estimates and time use estimates to measure the redistribution between different age groups and the sexes in Germany. This approach is especially relevant in the light of demographic change and the accompanied ageing of the population. The results become important when considering the demand for change in the "old" gender contract (Esping-Andersen et al. 2001), as the traditional male breadwinner model will most likely be revisited due to changes in the age structure of the population (Esping-Andersen et al. 2001). The impact of demographic change on gender systems has attracted little attention so far. A review by Mason (1995) offered some indications that demographic change could lead to a less stratified gender system. The effects of ageing on women and on their prospects on the labour market have also been studied to some extent (Auth 2004, 2006). Some scholars have predicted that there will be a change in female employment patterns over the coming decades (Al/mendinger/Ebner 2006; Kistler/Hilpert 2001; Pack et al. 2000). In addition to providing total production and consumption estimates, our study offers insights into the private intra-household redistribution of time and money. It contributes to the debate on the private pillar of the generational (Albertini et al. 2007) and gender contract, which has not attracted much attention so far.

Results on the monetary lifecycle show that there is a considerable redistribution of resources from men to women. Unlike earlier studies, we have taken production, consumption, as well as transfers of time and money into consideration. While men generate an overall lifecycle surplus, women need resources in addition to their labour income to finance their consumption at all ages. But after we take unpaid domestic labour into account, we find that male and female lifecycle patterns resemble each other. Although the observed gender gap diminishes, we still observe higher flows to women. By applying the specialist replacement method in monetising housework and care, the remaining differences can be attributed to the corresponding lower wages.

The paper is organised as follows. Section 2 provides an overview of the methods and data used to compute the monetary and time use results differentiated by age and gender. In the third section, the results are presented, with the monetary lifecycle shown first, followed by the time-adjusted estimates. Section 4 addresses possible consequences of an increase in female labour force participation on the lifecycle for men and women. Section 5 presents our conclusions. 


\section{Methods and data}

In this analysis, monetary and time use estimates of age-specific production, income and transfer patterns are combined to assess the differences in these variables by gender and to show inter-age as well as inter-gender redistribution of resources in greater detail. This allows us to overcome the deficiencies of a pure market perspective, and to add new insights into work/leisure and consumption/saving decisions within households. The monetary estimates are obtained by following the standard methodology of the National Transfer Accounts, ${ }^{1}$ decomposed by gender. The theoretical framework is based on Samuelson (1958), Diamond (1965), and Lee (1994). The NTA methodology quantifies most inter-age redistributions in a cross-sectional setting for a respective year. In order to construct NTAs by gender, a micro survey to estimate age utilisation profiles is needed. These age patterns of education, housing, labour income or utilisation of public transfers such as pensions, health care or general public services can be used to assess the importance of the age factor in an economy or to study the impact of population ageing as the most prominent examples.

The German Income and Expenditure Survey in 2003 (Einkommens- und Verbrauchsstichprobe, or EVS) serves as the basis for the relative age shares. We have chosen to use the National Transfer Accounts for 2003 because the latest time use estimates available are from 2002; thus, the non-monetary and monetary estimates correspond closely. The EVS is based on a representative quota sample of Germany's private households, and covers information on income, consumption, transfers, savings, and assets. For three months, the participating households provide detailed records of their income and expenditures. The EVS for 2003 includes around 50,000 households, and is representative of households with a monthly net income of less than 18,000 euros (for a methodological overview, see Statistisches Bundesamt (2005)). The EVS dataset contains most of the variables of interest by household members, the inflows are reported from an individual perspective. In cases where individual data is not available, as for example for food consumption, an equivalence scale is employed to allocate shares to household members (Deaton 1997). To estimate the net transfer of a specific age group, the consumption by age (net of taxes) is deducted from the output. As all items are consistent with the National Income and Product Accounts, the compensation of employees including employer's contributions for social security is used for computation.

Both, the monetary and the time use estimates employ a synthetic cohort approach. As longitudinal data are not available, we have to rely on a cross-sectional setting. This does not seem to pose too many problems, as results from repeated cross-sectional data expressed relative to mean labour income do not vary considerably over time (Kluge 2011). In addition to income and consumption, the EVS in-

1 National Transfer Accounts measure economic flows across age groups consistent with the National Income and Product Accounts. For more detailed information see www.ntaccounts. org. 
cludes all of the relevant public transfers to households, and it allows for estimations of private intra-familial flows and asset income or savings. Private asset income consists of capital income plus net property income for households, corporations, and non-profit institutions serving households (NPISHs). The allocation of some transfers such as inter-household transfers or child allowances to household members is rather difficult. Therefore we assume that these transfers are in between or to household heads who then grant an intra-household transfer for consumption. As it is impossible to estimate this more accurately without additional data sources or assumptions we admit this problem. Sensitivity analysis showed that the bias in the results is rather small as it is mainly items of lower importance or smaller magnitude that are difficult to allocate. To forecast future public benefits, we would have to change our approach as child allowances are only paid if you have children. In this case they should be connected to the children and not to the household head.

Furthermore, population estimates are needed to assess per capita consumption, income, and transfers by age and sex. These are available in one-year age groups, and are provided by the German Federal Statistical Office (Statistisches Bundesamt 2009a). To ensure that they fit the UN System of National Accounts and that they are nationally representative, the per capita age profiles are scaled to match at the macroeconomic level. The macro controls obtained from the national accounts of the corresponding year are usually not available by sex. Thus, the survey share for the corresponding item is used, and is assumed to hold true at the population level.

Age-specific estimates for in-kind transfers are obtained from official records about health, education, and "other". Age-specific expenditures for education are estimated by summing up the unit costs per student per level of school, weighted by the number of students at each level. The utilisation profile that helps to divide health care costs by age and sex is provided by the costs of diseases (Statistisches Bundesamt 2007). The "other" category contains the remaining non-age-specific costs that have a flat distribution over the synthetic lifecycle, and do not differ by sex. Information about consumption, income, and the age utilisation of public expenditures and revenues is provided in the National Transfer Accounts database for Germany (Kluge 2009)

Having outlined the methodology for obtaining the market lifecycle results for men and women, we now add non-market variables to the picture. To estimate production, consumption, and transfers in the household, the Time Use Survey 2001/02 is employed. The scientific use files for Germany include 5,400 households, 12,600 individuals, and 37,700 diary entries. Individuals were asked to fill in a calendar for three representative days, reporting all of their activities that require at least 10 minutes of attention. All of the activities satisfying the third-party rule (Reid 1934) are identified by age and gender. These are activities that can be outsourced such as childcare, cooking or gardening but not sleeping for example. The time spent per day on cooking, cleaning, or caring for each individual of a respective age group is then monetised using the average wages of the respective occupation (see Table 1). The adjustment factor corrects for overestimation of household activities. This is necessary, as the individual in the household is assumed to lack the efficiency and 
Tab. 1: Wages and adjustment factors by occupation, Germany, 2006

\begin{tabular}{lcc}
\hline Occupation & Gross hourly wage (in euros) & Adjustment factor \\
\hline Cook & 11.28 & 0.75 \\
Caretaker & 13.59 & 0.75 \\
Unskilled worker & 11.10 & 0.75 \\
Cleaner & 10.08 & 0.75 \\
Gardener & 13.00 & 0.75 \\
Eldercare helper & 13.14 & 1.00 \\
Nursery teacher & 15.08 & 1.00 \\
\hline
\end{tabular}

Source: Statistisches Bundesamt 2009b, NTA methodology

proficiency of a trained cook or gardener. For other activities, such as those that would otherwise be performed by a nursery school teacher or an eldercare helper, we think that this approach is not appropriate, as the time spent with children or elderly people should be fully accounted for.

Another approach for assigning a value to, for example, childcare is the concept of opportunity costs. Here, we value housework with the respective labour income a woman could earn in the market. While childcare is a service, the skill level of the provider is important, as the care children receive can affect their outcomes over the long term. The finding that families play a crucial role in determining the educational attainment of children (Ermisch/Francesconi 2001) suggests that this is the case. Thus, if we were to take into account the opportunity costs for childcare, the gap between men and women could further decrease, as it is typically the woman who stays home and provides care.

\section{$3 \quad$ Results}

The decomposition of production by age and gender usually focuses on market production of men and women. Figure 1 (solid lines) shows the hours spent on marketrelated work by men and women. We see the familiar picture: Men on average start working a little earlier than women. When they are in their early twenties, the hours spent on market-related work are almost similar for the two sexes. From around age 25 onwards, the working hours of women are lower at slightly above 20 hours per week, and then gradually decline to zero after the age of 50. Prime-aged men work almost twice as many hours as women (about 37 hours per week on average), and working hours do not start to decline until around the age of 60 . The dashed lines in Figure 1 show the total working hours of both sexes. These estimates include housework like cooking and cleaning, as well as childcare and eldercare. The total number of working hours are slightly higher for women under the age of 50. During the following decade, men are working slightly more, mainly until the transition to retirement. From age 65 onwards, women are again working more hours, exclu- 
Fig. 1: Working hours by age and gender, Germany, 2001/02

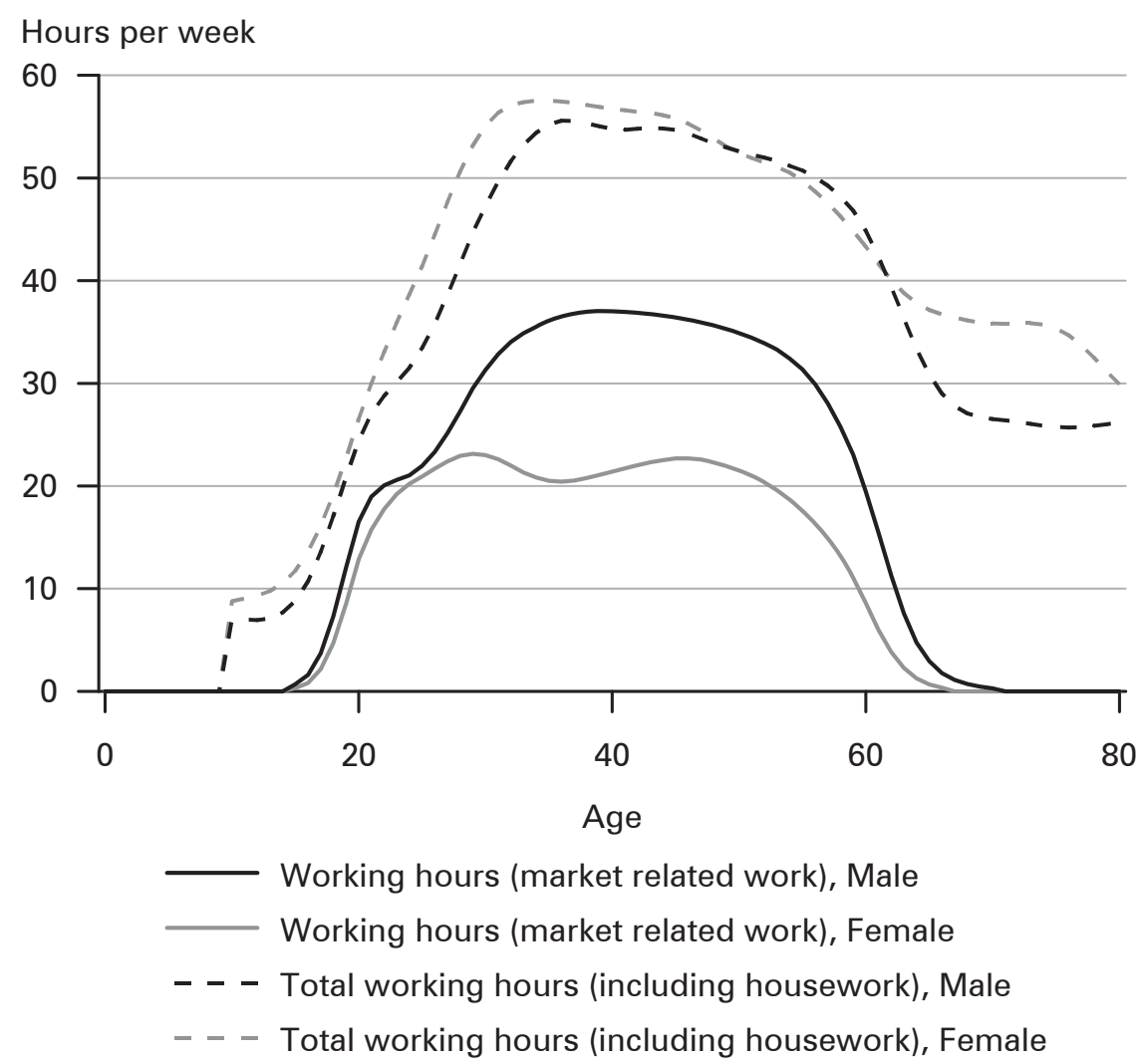

Source: Time Use Survey 2001/02, own calculations

sively due to household production. Overall, it can be argued that the amount of time spent working in any form is comparable for men and women. Previous studies have produced similar results for many Western countries. Sometimes referred to as the iso-work phenomenon, these findings suggest that there is no statistically significant gender difference in the amount of time spent working and not working (Burda et al. 2012).

The hours spent working in market and household production are reflected in the results on income, consumption, and transfer patterns by gender. The shortage of labour income is the main driver for the substantial public and private intergender flows.

Figure 2 depicts the monetary lifecycle of both sexes. Labour income from market-related work amounts to 40,000 euros annually for a prime-aged man, while women earn about 20,000 euros on average. The early labour market exit of women creates a gap of eight years between men and women. In consumption, only minor differences can be seen at older ages. These almost exclusively result from health care costs above the age of 50 (measured by the costs of illnesses by gender). The 
Fig. 2: Lifecycle deficit by gender, Germany, 2003

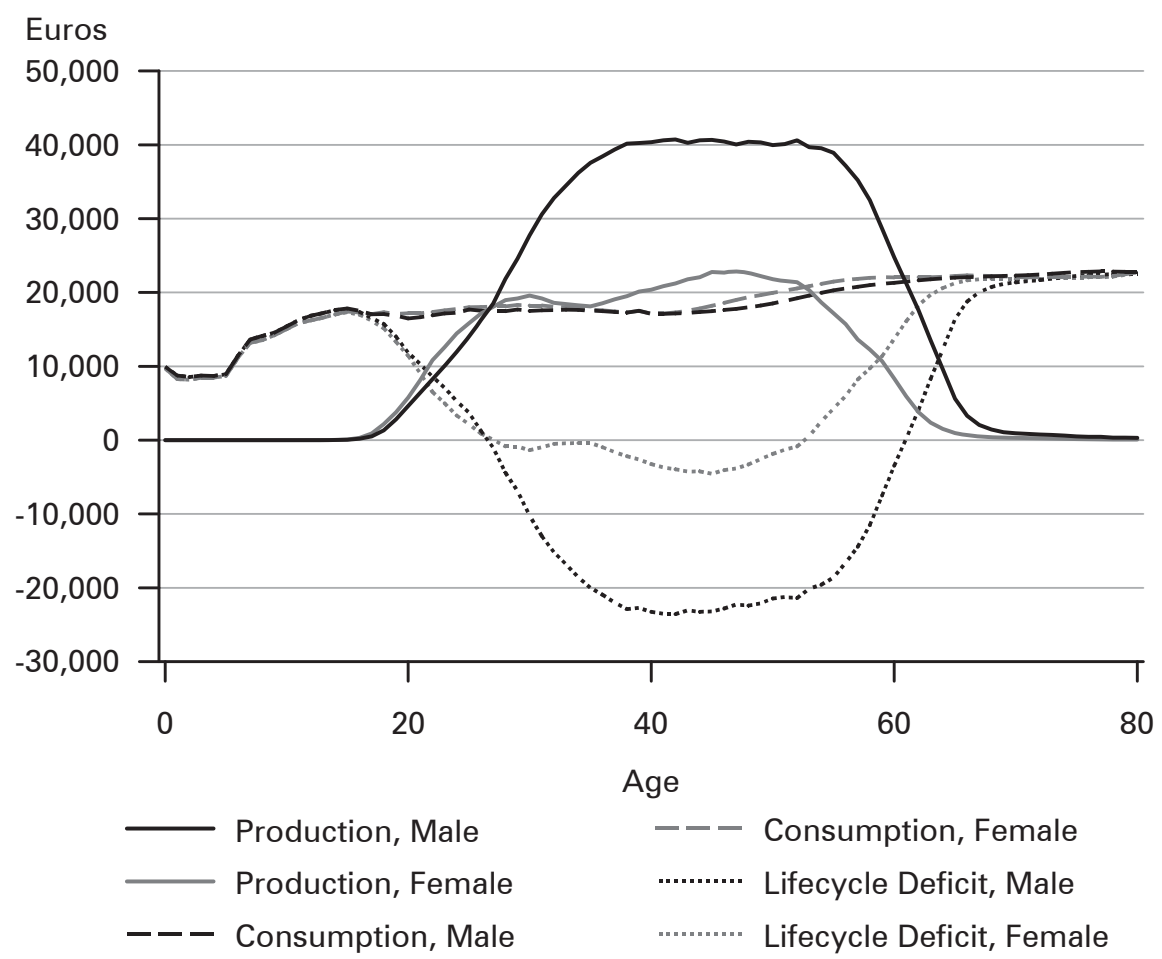

Source: EVS 2003, National Accounts 2003, own calculations

difference between consumption and income denotes the lifecycle deficit, or the amount of consumption that is not covered by individual labour income. For men on average, the surplus period lasts from age 27 to age 60 , and the surplus is significantly positive. As Figure 2 refers to the lifecycle deficit, positive values indicates a deficit and negative values indicate a surplus (the same applies to Fig. 6). For women, the surplus period is much shorter, only lasting from age 28 to age 52 , and the surplus amount is rather small. At the population level, this means that women's consumption share of 52 percent corresponds to a labour share of only 36 percent. Almost 300 billion euros are redistributed to women to finance male as well as female consumption.

The consumption of an individual in this framework could be financed through labour income, public or private transfers, or asset-based reallocations (savings, capital income or debt). Public transfers vary quite substantially between men and women. The transfers to households are decomposed into public pensions, illness and disability benefits, unemployment and family benefits, housing, and other remaining transfers. Public pensions for women amount to 11,000 euros per year, while men receive around 17,000 euros per year (Fig. 3). The payments for illness and disability are small when expressed in per capita values (about 1,000 euros 
Fig. 3: $\quad$ Public benefits by gender, Germany 2003

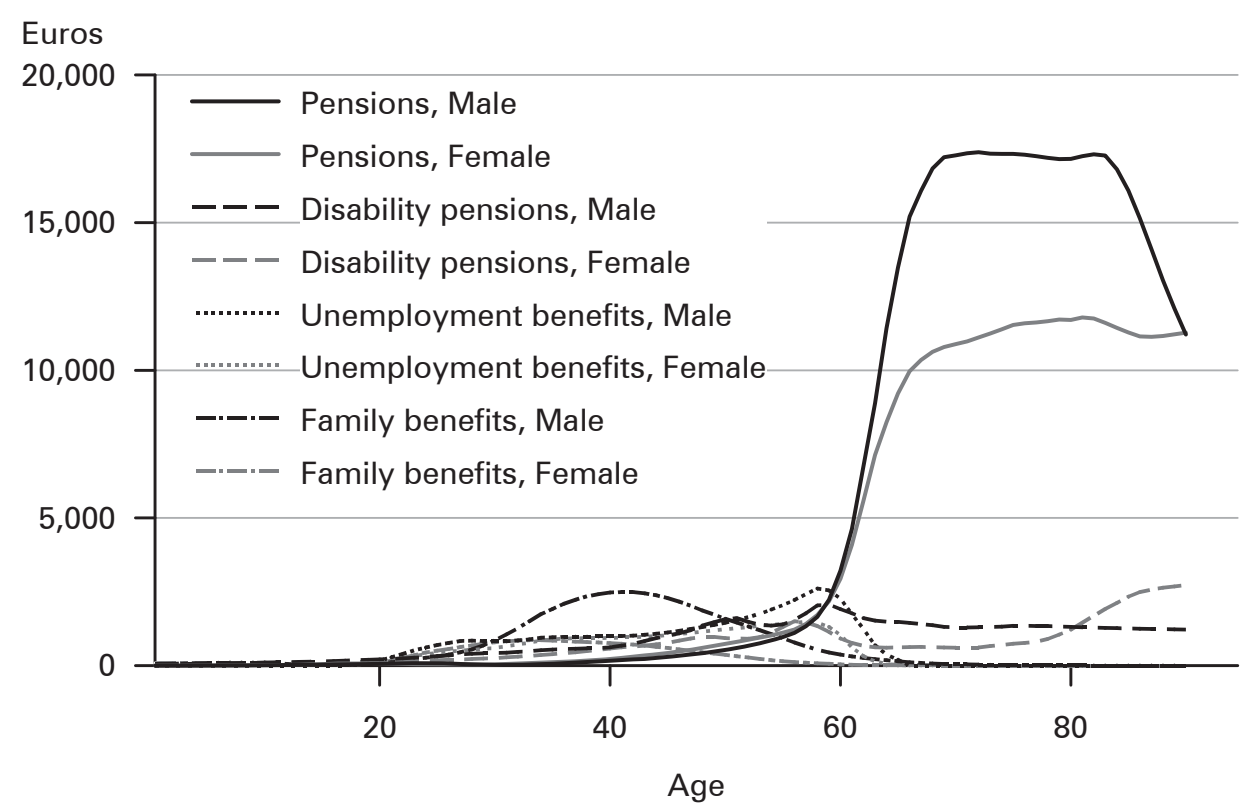

Source: EVS 2003, VGR 2003, own calculations

annually). The age profile shows a pronounced increase in payments around the entry to retirement. Thereafter, both profiles drop to lower amounts, with the only significant rises in income stemming from disability payments to women after the age of 80 . Family benefits are received at prime working ages, and the values are higher for men because the methodology assigns family transfers for children to the household head, who then makes an intra-family transfer to the dependent child. In the survey, the household head is more likely to be a man than a woman, but using another assignment method would not alter the picture considerably. Child allowances are rather small shares of transfers to households in per capita terms, as all other payments are dwarfed by public pensions. Other transfers are comparable for men and women. The overall inflow profile of public transfers is very similar for men and women until they reach their early thirties, because education, health, and other transfers are the same for male and female children. The gap widens later in life, and amounts to about 7,000 euros annually for a 70-year-old individual. It is not until the age of 87 that women start to receive slightly higher transfers than men. While the transfer inflows are similar, we find considerable discrepancies in public transfer outflows, which include labour, asset, and income taxes (Fig. 4). Women pay 37 percent of all collected taxes, but receive 48 percent of public transfers. Taxes on labour are reported on an individual basis in the survey. We can only show these public transfer outflows for an average individual and do not take into account tax splitting of married couples. In this case, we would have to estimate the results for different household types. In the case of asset taxes, we should note that 
Fig. 4: Public revenues by gender, Germany 2003

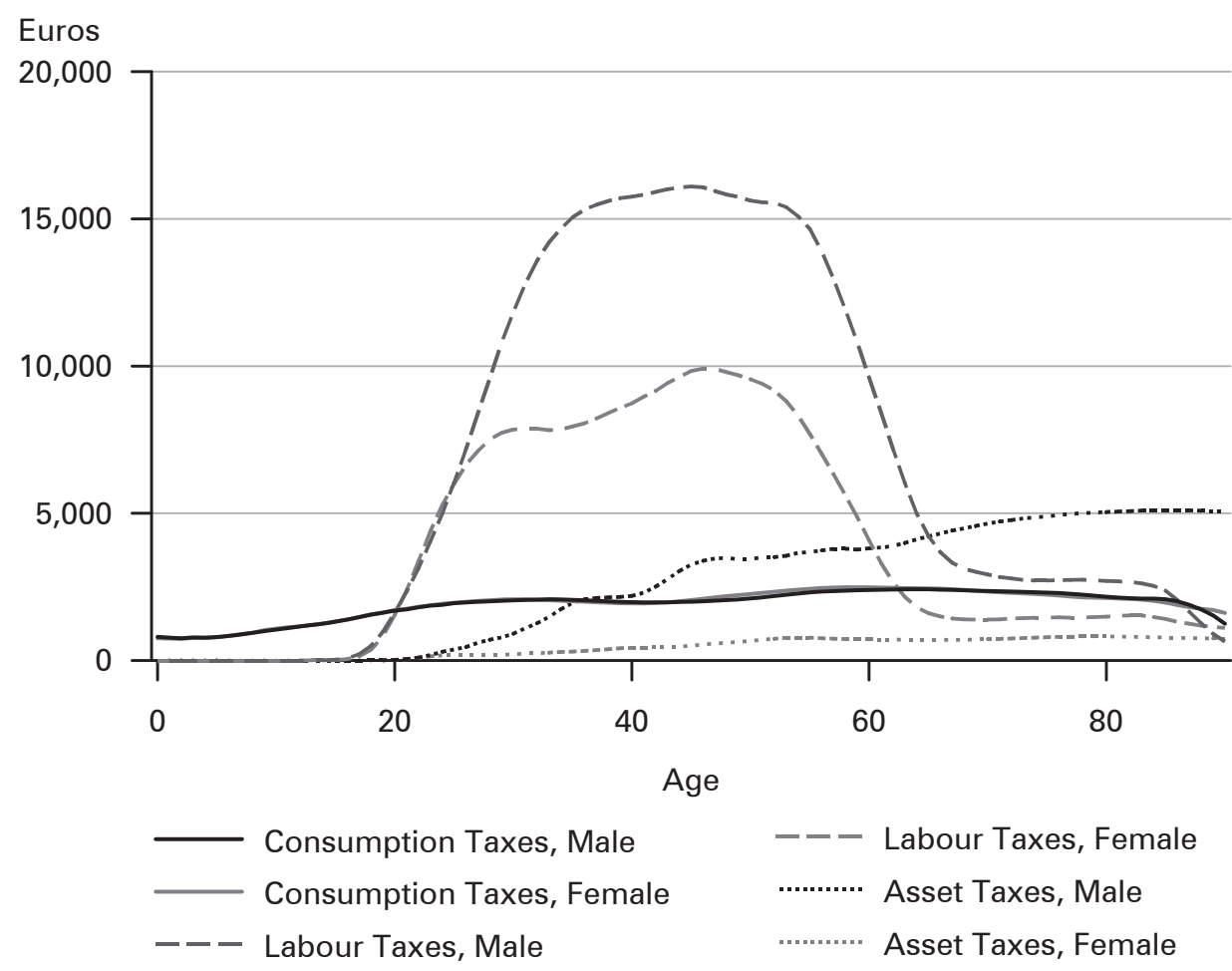

Source: EVS 2003, VGR 2003, own calculations

these flows are assigned to the individual defined as household head. Because the household head is often the male respondent in the survey, the gender division of these flows could be over- or underestimated. However, using another method in which these flows are shared equally among all of the adult household members or according to their household income share does not alter the profiles substantially. This is because most of the tax revenues are generated by taxes on labour income and contributions to social security, both of which are distinguishable by gender. The amounts paid in value-added taxes on consumption are comparable, as men and women consume in the same manner. In total, women have a public net payment shortfall of 124 billion euros (5.6 percent of GDP).

For private transfers, we observe very similar patterns for men and women up to age 30. Transfers for health or education hardly differ between the sexes. However, at prime working ages we find significant inter-gender flows of resources to finance all of the family members' consumption. As the disposable income and public transfer flows to men are higher, they are net givers. In total, men transferred 155 billion euros to women in 2003 (or seven percent of GDP). The redistribution within the household is higher than through the public sector. Still, these results have to be interpreted with caution. We use the synthetic cohort approach, as longitudinal data 
are missing for a number of variables. The increasing labour force participation of women and changing gender attitudes could alter the results in the future. Still, it is usually women who interrupt their careers to take maternity leave, even among younger cohorts. Thus, while these numbers may decrease, we do not expect them to reverse or reach the same level in the coming decades. An interesting decomposition would involve measuring economic flows between men and women separately for East and West Germany, in order to see how the flows alter in the more gender-equal East. But this is not easy to do even for male individuals, as the East is still subsidised significantly by the West. (Kluge 2010).

Summing up our observations about the monetary lifecycle, we can conclude that the resource redistribution to women flows through public and private channels. When we look at how women's monetary lifecycle deficit of 370 billion euros $^{2}$ is financed, we find that 34 percent comes from public transfers from men, and 43 percent comes from private channels, mainly in the form of intra-household transfers between the partners. The remaining 22 percent of the deficit is covered by assets, mainly between the ages of 50 and 70 during the transition to retirement.

When we look at the monetary results, we find that the male breadwinner model still prevails. But how do the observed consumption, income, and transfer patterns change if unpaid domestic labour is accounted for? The traditional division of household labour is still prevalent in Germany, as has been reported elsewhere (Wenger et al. 2009). In Figure 5, the time use estimates for both sexes are displayed by age. All household production increases with age for both sexes (except childcare). On average, men only work part-time in the household. For women, the time spent on cooking, cleaning, and childcare is two- to three times higher, expressed in minutes per day. The estimates for shopping are similar, and in the categories of gardening and construction, men show slightly higher values than women. Overall, the mean amount of time women spent on unpaid home production across all age groups is around four hours per day, compared to only 2.5 hours for men. Focusing on individuals under 50 , we can see that the gap is even wider ( 3.6 hours for women and 1.7 hours for men).

In the next step, the time use estimates are valued with representative wages in order to monetise the time spent on unpaid domestic labour. The wages and adjustment factors used have been displayed in the previous section. In general, the mean wage for a given task, such as cooking or cleaning, has been used (specialist replacement method) to estimate home production and consumption. For items that require training or special expertise, wages are adjusted downward to account for the fact that an unskilled person is performing the task who is not necessarily as efficient as a professional cook or cleaner.

The household production by gender can be derived from the time use files. Overall, we see a reversed picture compared to the one for market production, in which women are shouldering the lion's share of work. At the peak for both sexes,

2 For comparison, males generate a surplus of 120 billion euros. Using the non-gendered National Transfer Accounts, we find that the lifecycle deficit amounts to 265 billion euros. 
Fig. 5: Time use estimates by gender, Germany, 2001/02
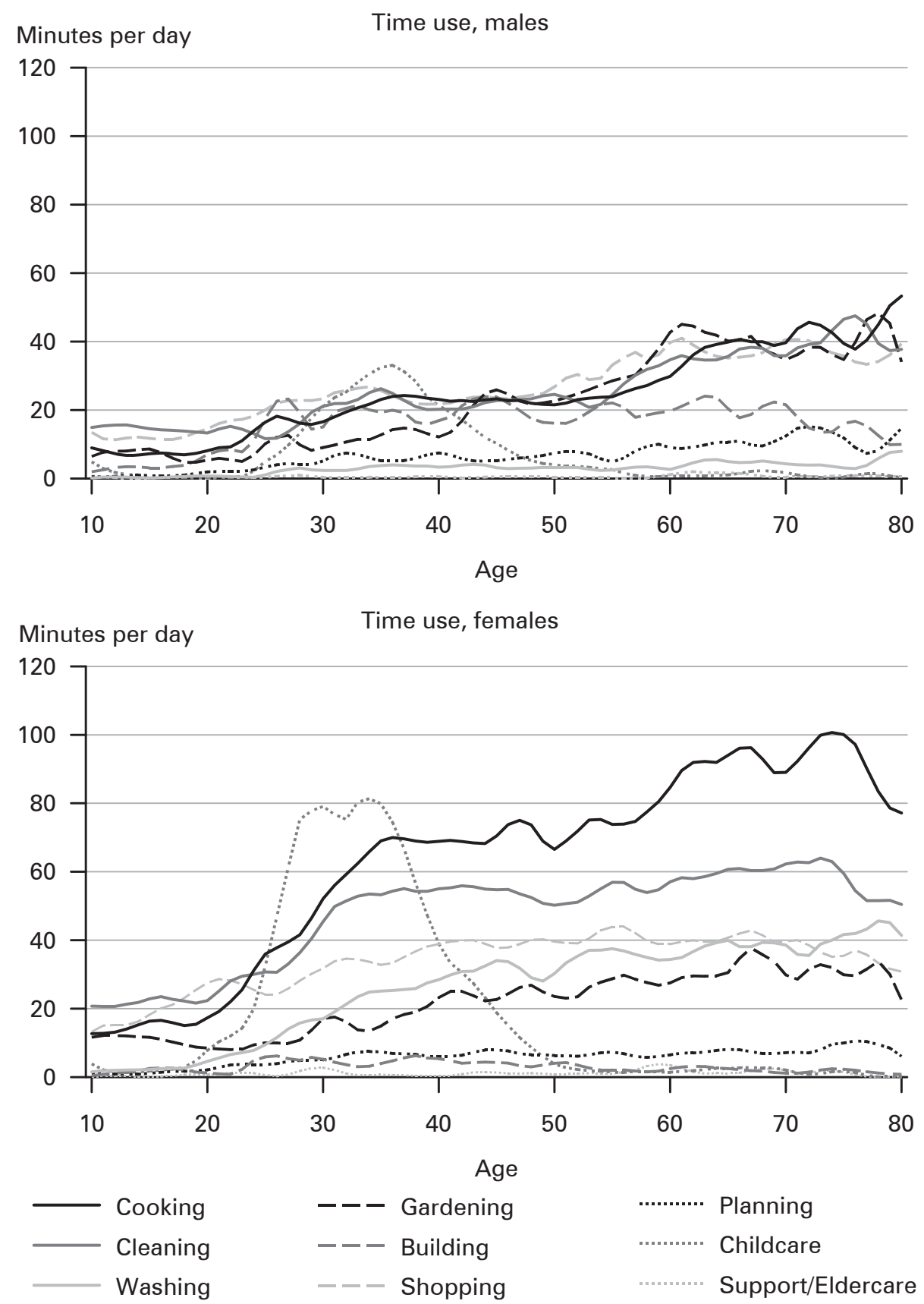

Source: Time Use Survey 2001/02, own calculations 
which occurs around the age of 30 , men contribute around 10,000 hours annually to unpaid home production, compared to around 20,000 hours for women. Thereafter, the gap starts to narrow, shrinking to about 3,000 hours during retirement. The consumption of unpaid domestic housework does not differ across sexes. We assume that boys and girls receive the same care, and that all of the household members consume the same amount with respect to washing dishes or cooking. The overall household production for cooking and cleaning is thus allocated to all of the individuals equally. Childcare or eldercare is allocated to the dependent household members of the respective ages. Overall, this means that, through intra-household channels, services worth around 100 billion euros are generated by women and consumed by men. This constitutes around two-thirds of the private monetary streams to women. The main reason why women are not able to entirely equalise the transfers is that wages for unskilled home production are low. When using an opportunity cost approach to value women's work the transfers would be even higher.

Monetising the time use estimates allows us to take a closer look at the overall production and consumption patterns and the lifecycle deficit of men and women (Fig. 6). Including the time spent in home production reduces the gender gap in

Fig. 6: Time use adjusted lifecycle deficit by gender, Germany, 2003

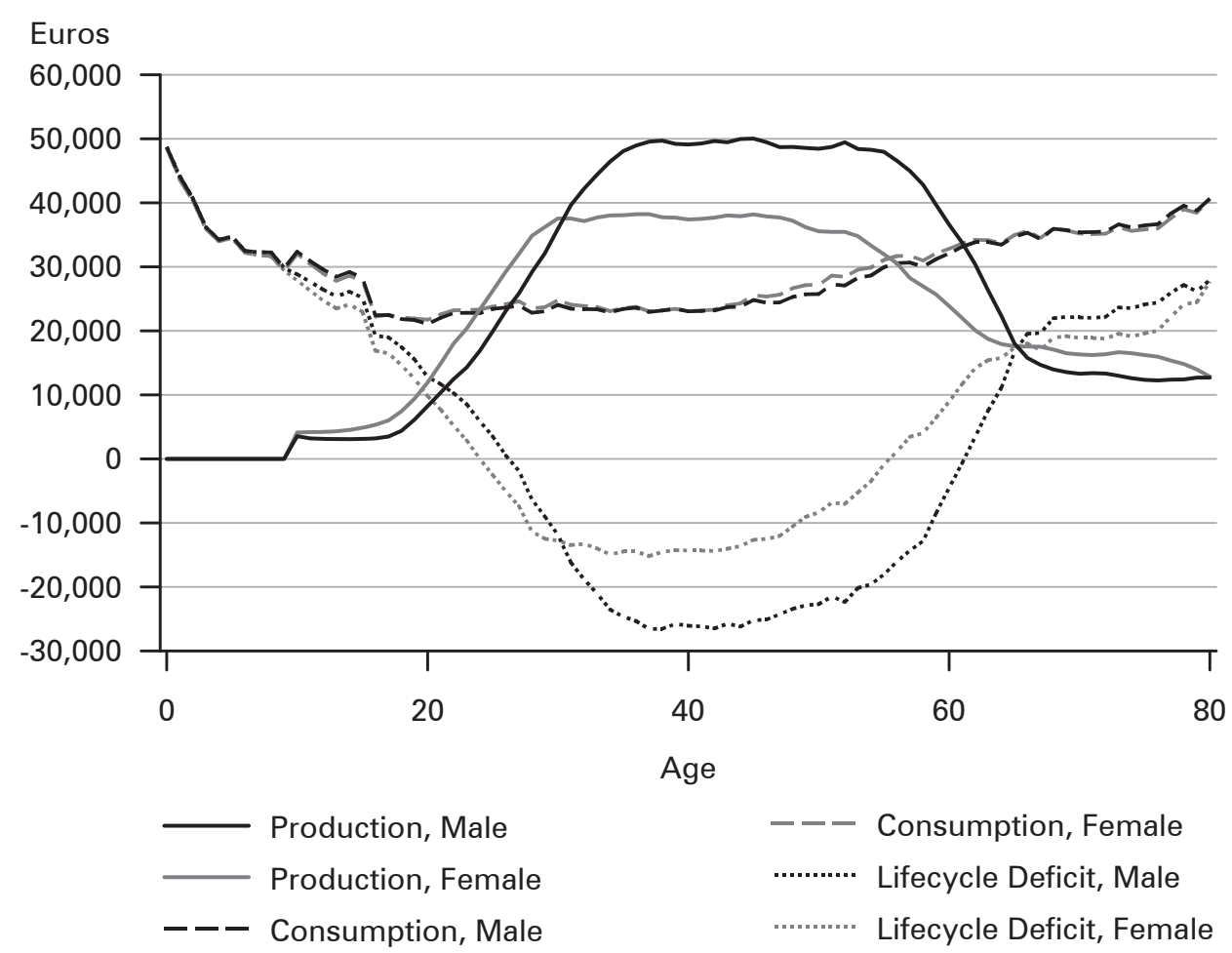

Source: EVS 2003, National Accounts 2003, Time Use Survey 2001/02, own calculations 
lifecycle deficits substantially. Here it can be seen that women, on average, start working three years earlier than men, and men only start working longer hours than women when they reach their early thirties. At retirement ages, women again work more than men, solely due to unpaid domestic work. Overall, we find that while women's labour accounts for only 35 percent of the total work force on the market, the share of work performed by women rises to 46 percent if housework is also considered. Consumption patterns over the lifecycle do not differ between the sexes. Here we find differences comparable to those already observed, except for children under the age of 10 whose lifecycle deficits increase due to the childcare they consume within the household. Accounting for unpaid domestic labour substantially decreases the lifecycle deficit of women. While the monetary estimate showed that consumption exceeded market female production by 17 percent of GDP (or 370 billion euros), the gap now decreases to 11 percent of GDP. A substantial share of the deficit can be financed through asset-based reallocations.

Against the background of demographic change the differences between men and women in the amount of time they allocate to market work and housework might be subject to change. Demographic change in the labour market context usually refers to the decreasing number of people of working age who will have to support an increasing number of dependents (Börsch-Supan 2003). Figure 7 depicts the total dependency ratios for East and West Germany (young $(<15)$ and old $(65+)$ dependency ratio) in the conventional age brackets. The increase is more pronounced in the East, with each worker having to support more than one person. While the total dependency ratio is calculated without accounting for who actually produces and who consumes in a society, the support ratio takes this into account. It shows a more detailed picture, as it takes into account the real dependencies, and is, for example, used to calculate demographic dividends (Mason/Lee 2006). The support ratio shows that, currently, about 0.7 producers take care of one consumer in the East. In the decades to come, this ratio will also apply to the West. In response to these projections, there are frequent calls for an increase in female labour force participation. The female employment rate in Germany was slightly less than 60 percent in the year corresponding to the time horizon of the study. It has since risen to 67 percent, but remains six percentage points lower than the average for Germany (OECD labour market statistics). But what does the increase in female labour market participation rates imply for the distribution of total work by gender?

As a projection of future overall consumption, income and transfer patterns would have to take into account various interaction effects and a model on behavioural changes, we will just illustrate two short ideas. First, we could keep the isowork amount constant. This would mean that the total number of hours worked by women would not increase. Thus, women would perform less unpaid domestic labour. If we assume that the shifts from non-employment to part-time employment, or from part-time to full-time employment, are comparable in all age groups, we find that, at the population level, 47 million hours would need to be redistributed. In this case, the iso-work amount of women would remain constant, and 30,000 individuals working 30 hours per week on average would be needed to close the gap. If we assume that the excess of housework is split between the household members, 
Fig. 7: Support and total dependency ratios, East and West Germany, 1950-2050

Support and dependency ratio (in percent)

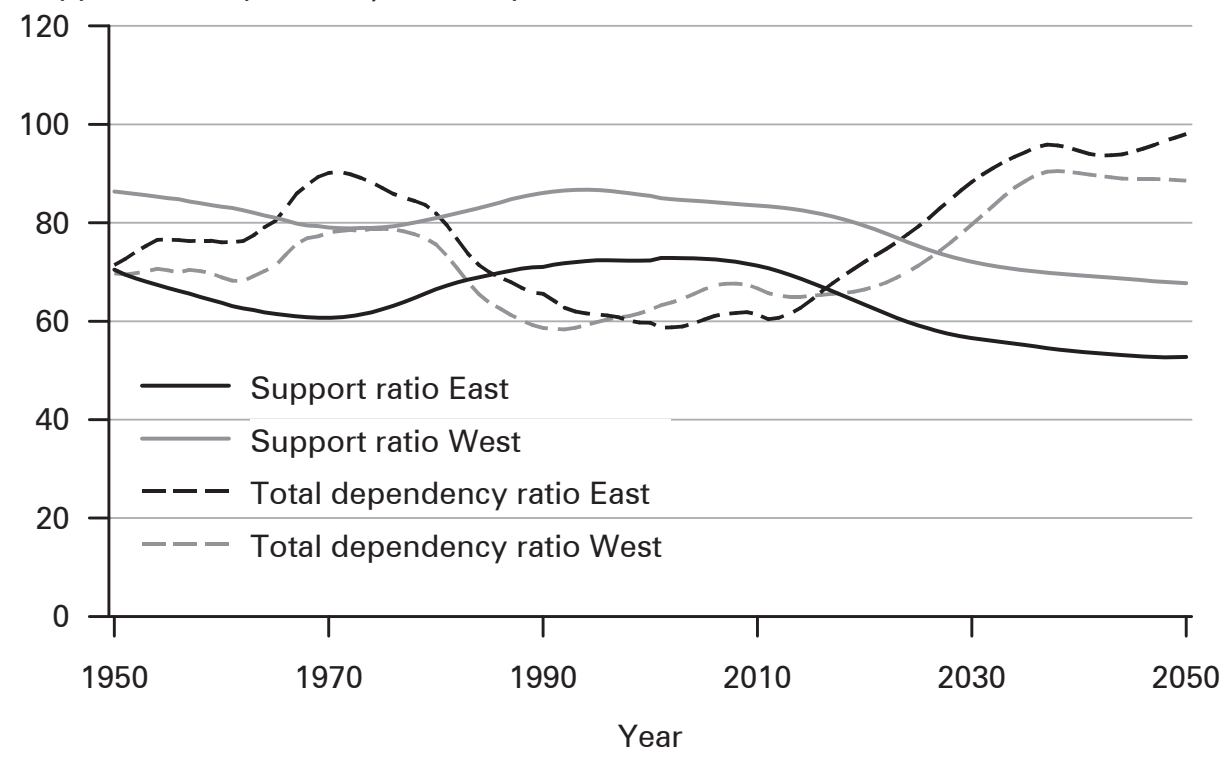

Source: Federal Statistical Office, own calculations

each individual would have to increase his or her weekly working hours by about 45 minutes. The specialist replacement method of outsourcing housework would mainly apply to cleaning and other easy housework tasks, while care-related tasks are less likely to be outsourced due to attitudes on childcare or old-age care. In the future, smaller birth cohorts who are currently middle-aged will have to provide care for their own offspring, their parents, and, in the case of one-child families, also their parents-in-law. Unless more flexible arrangements are introduced, the health and long-term care insurance systems will face challenges. If a more recent time use survey was available - which, unfortunately, is not the case - we would get a better idea of which solutions households are now choosing. It is, however, clear that the increased demand for female market labour and the increased demand for care will challenge the traditional labour division.

\section{$4 \quad$ Discussion and Outlook}

This study shows how market and non-market economic variables are distributed over the life course by gender. The estimates are based on combined monetary and time use estimates, and show gender differences in patterns of total production, consumption, and transfers. The monetary results reveal that there is a substantial redistribution of resources from men to women. The majority of transfers ( 155 billion 
euros) are made in the private sector, mainly via intra-household transfers between partners. Another 124 billion euros result from public transfer redistribution as the taxes paid by women are insufficient to finance their public transfer utilisation. About 20 percent of the lifecycle deficit women face is financed by asset-based reallocations mainly during the transition to retirement.

This large gap between women's labour income and their consumption (lifecycle deficit) is then contrasted with the results from estimates of unpaid home production. When household services such as cooking, cleaning, and caring are added into the equation the gender gap in production and the corresponding lifecycle deficit decrease dramatically. When the monetary and time use approaches are combined, we see an increase of 11 percentage points in women's labour contributions (up to 46 percent). The consumption patterns of men and women are roughly the same except for minor items such as health care costs by age and sex. Overall, the profile shows increases among the young and the old, but otherwise remains fairly stable over the synthetic cohort. Monetising the time use estimates of housework reduces the lifecycle deficit of women from about 17 percent to 11 percent of GDP. A considerable share of the lifecycle deficit can be financed via asset-based reallocations.

The main reason why the gap in the analysis cannot be closed is because women earn lower wages for both market and non-market work. Women are more likely than men to choose employment that is generally paid poorly (nursing home care, service sector), and even if they perform the same tasks women earn about 22 percent less than men in Germany (Rubery et al. 2005). In addition, housework was valued using the specialist replacement approach which means that the generally low wages of a cleaner or a cook are employed in the estimations (in contrast to, for example, the opportunity costs approach). Still, we find that unpaid housework contributes substantially to closing the gender gap observed for regular market production.

In the future, the profiles will change along with increasing female labour force participation rates. It is not unlikely that due to demographic changes female wages will rise (Ottaviano/Peri 2006) which would mean that a growing number of women will increase the hours they work per week. If that occurs, the division of household labour is expected to change. If the total amount of hours worked by men and women were to remain constant, new employment opportunities would be created for low-skilled workers. Unfortunately, the results of this study are obtained employing the synthetic cohort approach as longitudinal data on monetary and time use are not available jointly. Thus, we can only speculate on the future of these age profiles as it is hard to distinguish between age and cohort effects. In the future, it would be interesting to investigate differences in the lifecycle by gender between East and West Germany. The substantially higher female labour force participation rates and more equal gender attitudes in the East which differ from those in the West for historic reasons could shed light on possible pathways for future lifecycle patterns. 


\section{Acknowledgements}

The author wishes to thank Gretchen Donehower, the participants of the European National Transfer Accounts workshop in Stockholm (2012) and two anonymous referees for their valuable comments and suggestions.

\section{References}

Albanesi, Stefania; Olivetti, Claudia 2009: Home production, market production and the gender wage gap: Incentives and expectations. In: Review of Economic Dynamics 12,1: 80-107 [doi: 10.1016/j.red.2008.08.001].

Albertini, Marco; Kohli, Martin; Vogel, Claudia 2007: Intergenerational transfers of time and money in European families: common patterns - different regimes? In: Journal of European Social Policy 17,4: 319-334 [doi: 10.1177/0958928707081068].

Aliaga, Christel; Winqvist, Karin 2003: How women and men spend their time. In: Statistics in focus: population and social conditions. Eurostat: Luxemburg.

Allmendinger, Jutta; Ebner, Christian 2006: Arbeitsmarkt und demografischer Wandel. In: Zeitschrift für Arbeits-und Organisationspsychologie A\&O 50,4: 227-239 [doi: 10.1026/0932-4089.50.4.227].

Andersson, Gunnar; Kreyenfeld, Michaela; Mika, Tatjana 2009: Welfare state context, female earnings and childbearing in Denmark and Germany. Stockholm: SPaDE Working Paper.

Antonczyk, Dirk; Fitzenberger, Bernd; Sommerfeld, Katrin 2010: Rising wage inequality, the decline of collective bargaining, and the gender wage gap. In: Labour Economics 17,5: 835-847 [doi: 10.1016/j.labeco.2010.04.008].

Anxo, Dominique 2002: Time allocation and the gender division of labour in France and Sweden. Annecy: Paper presented at the Symposium France/ILO 2002.

Anxo, Dominique et al. 2007: Time Allocation Between Work and Family Over the Lifecycle: A Comparative Gender Analysis of Italy, France, Sweden and the United States. Bonn: IZA Discussion Paper.

Apps, Patricia; Rees, Ray 2000: Public economics and the household. Cambridge: Cambridge Books.

Auerbach, Alan J.; Kotlikoff, Laurence J.; Leibfritz, Willi 1999: Generational Accounting Around the World. Chicago: University of Chicago Press.

Auth, Diana 2004: Die alternde Gesellschaft: Bessere Arbeitsmarktperspektiven für Frauen. In: Breit, Gotthard (Ed.): Die alternde Gesellschaft. Schwalbach/Ts.: Wochenschau verlag: 53-71.

Auth, Diana 2006: Frauenarbeit in einer alternden Gesellschaft. In: Ruhl, Kathrin; Schneider, Jan; Träger, Jutta; Wiesner, Claudia (Eds.): Demokratisches Regieren und politische Kultur. Post-staatlich, post-parlamentarisch, post-patriarchal? Münster: LitVerlag: 291-304.

Becker, Gary S. 1965: A Theory of the Allocation of Time. In: The economic journal 75,299: 493-517.

Biddle, Jeff E.; Hamermesh, Daniel S. 1990: Sleep and the allocation of time. In: Journal of Political Economy 98,5: 922-943.

Börsch-Supan, Axe/ 2003: Labor market effects of population aging. In: Labour 17: 5-44 [doi: 10.1111/1467-9914.17.specialissue.2]. 
Burda, Michael; Hamermesh, Danie/ S.; Weil, Philippe 2012: Total work and gender: facts and possible explanations. In: Journal of Population Economics 26,1: 239-261 [doi: 10.1007/s00148-012-0408-x].

Deaton, Angus 1997: The analysis of household surveys: a microeconometric approach to development policy. Baltimore: Johns Hopkins University Press.

Diamond, Peter A. 1965: National Debt in a Neoclassical Growth Model. In: The American Economic Review 55,5: 1126-1150.

Dustmann, Christian 2005: The assessment: gender and the life cycle. In: Oxford Review of Economic Policy 21,3: 325-339 [doi: 10.1093/oxrep/gri019].

Ermisch, John; Francesconi, Marco 2001: Family matters: Impacts of family background on educational attainments. In: Economica 68,270: 137-156 [doi: 10.1111/14680335.00239].

Esping-Andersen, Gøsta; Gallie, Duncan; Hemerijck, Anton; Myles, John 2001: A new welfare architecture for Europe. Report submitted to the Belgian Presidency of the European Union.

Kistler, Ernst; Hilpert, Markus 2001: Auswirkungen des demographischen Wandels auf Arbeit und Arbeitslosigkeit. In: Aus Politik und Zeitgeschichte B,3: 5-13.

Kluge, Fanny A. 2009: Transfers, consumption and income over the lifecycle in Germany. Rostock: MPIDR Working Paper, WP-2009-014.

Kluge, Fanny A. 2010: How East and West Germans finance their lifecycle consumption: evidence from NTA. Rostock: MPIDR Working Paper, WP-2010-027.

Kluge, Fanny A. 2011: The individual economic lifecycle and its fiscal implications in an aging Germany - Findings from National Transfer Accounts. Rostock: University of Rostock.

Kreyenfeld, Michaela 2010: Uncertainties in female employment careers and the postponement of parenthood in Germany. In: European Sociological Review 26,3: 351-366 [doi: 10.1093/esr/jcp026].

Lechner, Michael; Wiehler, Stephan 2009: Kids or courses? Gender differences in the effects of active labor market policies. In: Journal of Population Economics 24,3: 783812 [doi: 10.1007/s00148-009-0267-2].

Lee, Ronald D. 1994: The Formal Demography of Population Aging, Transfers, and the Economic Life Cycle. In: Martin, Linda G.; Preston, Samuel H. (Eds.): Demography of Aging. Washington, DC: National Academy Press Washington, DC: 8-49.

Lindh, Thomas; Malmberg, Bo; Palme, Joakim 2005: Generations at war or sustainable social policy in ageing societies? In: Journal of Political Philosophy 13,4: 470-489. [doi: 10.1111/j.1467-9760.2005.00233.x].

Mason, Andrew; Lee, Ronald 2006: Reform and support systems for the elderly in developing countries: capturing the second demographic dividend. Rome: Genus: 11-35.

Mason, Karen O. 1995: Gender and demographic change: What do we know? International Union for the Scientific Study of Population Liege (Belgium).

Oostendorp, Remco. H. 2009: Globalization and the gender wage gap. In: The World Bank Economic Review 23,1: 141-161.

Ottaviano, Gianmarco; Peri, Giovanni 2006: Rethinking the effects of immigration on wages. Cambridge: National Bureau of Economic Research.

Owens, Gary M. 2008: Gender differences in health care expenditures, resource utilization, and quality of care. In: Journal of Managed Care Pharmacy 14,3: 2. 
Pack, Jochen et al. 2000: Zukunftsreport Demographischer Wandel. Innovationsfähigkeit in einer alternden Gesellschaft. Bundesministerium für Bildung und Forschung: Bonn.

Polachek, Solomon W.; Xiang, Jun 2009: The gender pay gap across countries: A human capital approach. DIW-Berlin: SOEP Paper (227).

Raffelhüschen, Bernd 1999: Generational accounting in Europe. In: American Economic Review 89,2: 167-170.

Reid, Margaret G. 1934: Economics of household production. New York: J. Wiley \& Sons, Inc.

Rubery, Jill; Grimshaw, Damian; Figueiredo, Hugo 2005: How to close the gender pay gap in Europe: towards the gender mainstreaming of pay policy. In: Industrial Relations Journal 36,3: 184-213 [doi: 10.1111/j.1468-2338.2005.00353.x].

Samuelson, Paul A. 1958: An Exact Consumption-Loan Model of Interest with or without the Social Contrivance of Money. In: The Journal of Political Economy 66,6: 467-482.

Statistisches Bundesamt 2005: Einkommens- und Verbrauchsstichprobe - Aufgabe, Methode und Durchführung der EVS. [Income and Expenditure Survey-task, method and carrying out of EVS]. Fachserie 15,7. Wiesbaden: Statistisches Bundesamt.

Statistisches Bundesamt 2007: Gesundheit - Krankheitskosten 2002 und 2004 [Health care-Disease expenses, 2002 and 2004]. Wiesbaden: Statistisches Bundesamt.

Statistisches Bundesamt 2009a: Bevölkerung Deutschlands bis 2060. 12. koordinierte Bevölkerungsvorausberechnung. Wiesbaden: Statistisches Bundesamt.

Statistisches Bundesamt 2009b: Verdienste und Arbeitskosten - Verdienststrukturerhebung 2006, Verdienste nach Berufen. Statistisches Bundesamt: Wiesbaden.

Wengler, Annelene; Trappe, Heike; Schmitt, Christian 2009: Alles wie gehabt? Zur Aufteilung von Hausarbeit und Elternaufgaben in Partnerschaften. In: Zeitschrift für Bevölkerungswissenschaft 34,1-2: 57-78 [doi: 10.1007/s12523-010-0033-2].

Werding, Martin 2005: Survivor Benefits and the Gender Tax Gap in Public Pension Schemes: Observations from Germany. München: CESifo Working Paper Series No. 1596.

Dr. Fanny A. Kluge ( $₫)$, Max Planck Institute for Demographic Research. Rostock. Germany. E-Mail: kluge@demogr.mpg.de

URL: http://www.demogr.mpg.de/en/institute/staff_directory_1899/fanny_annemarie_ kluge_1808.htm 


\section{Comparative Population Studies}

WWW.comparativepopulationstudies.de

ISSN: 1869-8980 (Print) - 1869-8999 (Internet)

Published by / Herausgegeben von

Prof. Dr. Norbert F. Schneider

Federal Institute for Population Research

D-65180 Wiesbaden / Germany

Managing Editor /

Verantwortlicher Redakteur

Frank Swiaczny

Assistant Managing Editor /

Stellvertretende Redakteurin

Katrin Schiefer

Language \& Copy Editor (English) /

Lektorat \& Übersetzungen (englisch)

Amelie Franke

Copy Editor (German) /

Lektorat (deutsch)

Dr. Evelyn Grünheid

\section{Layout / Satz}

Beatriz Feiler-Fuchs

E-mail:cpos@bib.bund.de

\author{
Scientific Advisory Board / \\ Wissenschaftlicher Beirat \\ Paul Gans (Mannheim) \\ Johannes Huinink (Bremen) \\ Michaela Kreyenfeld (Rostock) \\ Marc Luy (Wien) \\ Clara H. Mulder (Groningen) \\ Notburga Ott (Bochum) \\ Peter Preisendörfer (Mainz) \\ Zsolt Spéder (Budapest)
}

\section{Board of Reviewers / Gutachterbeirat} Martin Abraham (Erlangen)

Laura Bernardi (Lausanne)

Hansjörg Bucher (Bonn)

Claudia Diehl (Konstanz)

Andreas Diekmann (Zürich)

Gabriele Doblhammer-Reiter (Rostock)

E.-Jürgen Flöthmann (Bielefeld)

Alexia Fürnkranz-Prskawetz (Wien)

Beat Fux (Salzburg)

Joshua Goldstein (Berkeley)

Karsten Hank (Köln)

Sonja Haug (Regensburg)

Aart C. Liefbroer (Den Haag)

Kurt Lüscher (Konstanz)

Dimiter Philipov (Wien)

Tomáš Sobotka (Wien)

Heike Trappe (Rostock) 